\title{
Pengaruh Senam Kegel Terhadap Inkontinensia Urin Pada Lansia Di Balai Sosial Lanjut Usia Mandalika Mataram
}

\author{
Suhartiningsih $^{1}$, Wahyu Cahyono ${ }^{2}$, Martina Egho ${ }^{3}$ \\ ${ }^{12}$ Staf pengajar Sekolah Tinggi Ilmu Kesehatan Mataram \\ ${ }^{3}$ Mahasiswi Sekolah Tinggi Ilmu Kesehatan Mataram \\ Email : ningsihsuharti86@gmail.com
}

\begin{tabular}{l}
\hline Article Info \\
Article history: \\
Article Accepted: July 012021 \\
Publication : July 102021
\end{tabular}

\begin{tabular}{l}
\hline Keywords: \\
Lansia, $\quad$ Inkontinensia \\
Urin, Senam Kegel
\end{tabular}

Corresponding Author:

Suhartiningsih
Staf pengajar Sekolah Tinggi Ilmu
Kesehatan Mataram
Email : ningsihsuharti86@gmail.com

\section{PENDAHULUAN}

Indonesia menempati urutan kelima dengan jumlah lansia terbanyak didunia setelah Cina (200 juta jiwa), India (110 juta jiwa), Amerika Serikat (36,9 juta jiwa), dan Jepang dengan (20 juta jiwa) lansia. (Kemenkes RI, 2013). Berdasarkan hasil Susenas (2016), jumlah lansia di Indonesia mencapai 22,4 juta jiwa atau $8,69 \%$ dari jumlah penduduk di Indonesia. Lalu menurut data Kemenkes RI (2017), jumlah lansia di Indonesia mencapai 9,03\% dari jumlah penduduk di Indonesia. Hal ini menunjukkan bahwa Indonesia termasuk negara yang akan memasuki era penduduk menua (aging population) karena jumlah penduduknya yang berusia 60 tahun ke atas (penduduk lansia) melebihi angka 7 persen. WHO tahun 2013 menyebutkan bahwa sekitar 200 juta penduduk di seluruh dunia mengalami Inkontinensia urin, tetapi angka yang sebenarnya tidak diketahui karena banyak kasus yang tidak dilaporkan. Di Indonesia jumlah penderita Inkontinensia urin sangat signifikan. Diperkirakan bahwa 25-35\% dari seluruh orang tua

\begin{abstract}
Inkontinensia urin adalah pengeluaran urin yang tidak terkontrol, sering dialami oleh lanjut usia. Sekitar 200 juta penduduk di seluruh dunia mengalami Inkontinensia urin. Dan di Balai sosial lanjut usia mandalika mataram ada $41 \%$ pengaruh senam kegel terhadap Inkontinensia urin pada lanjut usia di Balai sosial lanjut usia mandalika mataram. Penelitian ini menggunakan desain penelitian pra eksperimental dengan rancangan one group pre-post test, dengan populasi 87 lansia, penentuan sampel menggunakan tekhnik purposive sampling, jumlah analisa menggunakan uji wilcoxon dengan bantuan spss versi 21 , dengan nilai sigifikansi $\leq 0.05$. Hasil penelitian menunjukkan sebelum perlakuan terdapat $23 \%$ lansia mengalami Inkontinensia urin ringan, $62 \%$ inkontinensia urin sedang, inkontinensia urin, $15 \%$ inkontinensia urin ringan, 35\% inkontinensia urin sedang dan $8 \%$ lansia inkontinensia urin berat. Hasil Uji wilcoxon menunjukkan nilai signifikansi $0.00 \leq 0.05$. Hasil penelitian ini menyimpulkan terdapat pengaruh Lanjut Usia Mandalika Mataram. Senam kegel sebaiknya rutin dilakukan oleh para lanjut usia dengan bimbingan para mentor di Balai Sosial Lanjut Usia Mandalika Mataram.
\end{abstract}

This is an open access article under the Lisensi Creative Commons Atribusi-BerbagiSerupa 4.0 Internasional 
akan mengalami inkontinensia urin selama kejadian seumur hidup Dibandingkan pada usia produksi (Onat, 2014). Inkontinensia urin akan bertambah berat saat berumur 65-74 tahun.(Aspiani,R.Y, 2014)

Sedangkan Di Balai Sosial Lanjut Usia Mandalika Mataram, setelah dilakukan studi pendahuluan pada bulan November 2018 menggunakan kuisioner SSI, tercatat bahwa dari 87 jumlah Lansia secara Keseluruhan terdapat 36 Lansia yang mengalami Inkontinensia urin. Tetapi penanganan Inkontinensia Urin masih sangat kurang. Menurut Informasi yang didapatkan dari petugas Balai Sosial Lanjut usia mandalika mataram sampai sejauh ini masalah Inkontinensia urin belum terkaji dan belum pernah diberikan penanganan berupa senam kegel. Salah satu penyebab penanganan Inkontinensia urin belum terlaksana adalah karena masyarakat belum tahu tempat yang tepat untuk berobat disertai kurangnya pemahaman tenaga kesehatan tentang inkontinensia urin (Depkes, 2015). Oleh karena hal tersebut, peneliti tertarik untuk melakukan penelitian apakah memang benar ada pengaruh senam kegel terhadap Inkontinensia uri pada lansia di balai sosial lanjut usia mandalika mataram.

\section{METODE PENELITIAN}

Penelitian Ini dilakukan di Balai Sosial Lanjut Usia Mandalika Mataram pada bulan Desember - Januari, 2018-2019 selama 6 minggu. Desain Penelitian dalam penelitian ini adalah Pra eksperimental dengan rancangan one group pre test dan post test. dengan teknik pengambilan sampel menggunakan purposive sampling, Teknik pengumpulan data dengan menggunakan instrument wawancara Kuisioner SSI (Sandvix Severity Indeks), dari 36 lansia yang mengalami Inkontinensia urin ada 26 orang lansia yang bersedia menjadi responden. Kemudian data pretest dan posttest di uji menggunakan uji Wilcoxon dengan nilai signifikansi $\leq 0.05$.

\section{HASIL PENELITIAN}

Tabel 1 Distribusi responden berdasarkan usia

\begin{tabular}{|c|c|c|c|}
\hline No & Usia & Frekuensi & presentase \\
\hline 1 & $60-74$ & 18 & $69 \%$ \\
\hline 2 & $75-89$ & 6 & $23 \%$ \\
\hline 3 & $\geq 90$ & 2 & $8 \%$ \\
\hline & umlah & 26 & $100 \%$ \\
\hline
\end{tabular}

Dari tabel dapat disimpulkan bahwa responden terbanyak pada kategori usia 60 - 74 tahun dengan jumlah 18 lansia (69\%), pada usia 75-89 tahun terdapat 6 lansia (23\%) dan pada usia > 90 tahun terdapat 2 orang lansia.

Tabel 2 Distribusi responden berdasarkan jenis kelamin

\begin{tabular}{|c|c|c|c|}
\hline No & Jenis kelamin & Frekuensi & Presentase \\
\hline 1 & Laki-laki & 5 & $19 \%$ \\
\hline 2 & Perempuan & 21 & $81 \%$ \\
\hline
\end{tabular}

Pada tabel 2 didapatkan data lansia wanita yang mengalami inkontinensia urin sebanyak $21(81 \%)$ lansia dan laki-laki sebanyak 5 lansia (19\%).

Tabel 3 Distribusi responden berdasarkan Pendidikan

\begin{tabular}{|c|c|l|l|}
\hline No & Pendidikan & frekuensi & presentase \\
\hline 1 & Tidak sekolah & 18 & $69 \%$ \\
\hline
\end{tabular}




\begin{tabular}{|l|l|l|l|}
\hline 2 & SD & 5 & $19 \%$ \\
\hline 3 & SMP & 3 & 12 \\
\hline 4 & SMA & 0 & $0 \%$ \\
\hline Jumlah & 26 & $100 \%$ \\
\hline
\end{tabular}

Pada tabel 3, Berdasarkan hasil penelitian tingkat pendidikan responden terbanyak pada responden yang tidak sekolah sebanyak 18 Lansia( 69\%), responden yang SD sebanyak 5 Lansia (19\%) dan responden yang SMP sebanyak 3 Lansia (12\%).

Tabel 4 Distribusi responden berdasarkan tingkat Inkontinensia Urin

\begin{tabular}{|c|l|c|c|}
\hline No & \multicolumn{1}{|c|}{ Tingkat keparahan } & frekuensi & Presentase \\
\hline 1 & Tidak Inkontinensia & 0 & $0 \%$ \\
\hline 2 & Inkontinensia Urin ringan & 6 & $23 \%$ \\
\hline 3 & Inkontinensia Urin sedang & 16 & $62 \%$ \\
\hline 4 & Inkontinensia Urin Berat & 4 & $15 \%$ \\
\hline 5 & $\begin{array}{l}\text { Inkontinensia Urin Sangat } \\
\text { berat }\end{array}$ & 0 & $0 \%$ \\
\hline & Jumlah & 26 & $100 \%$ \\
\hline
\end{tabular}

Dari Tabel 4, tingkat keparahan Penyakit Inkontinensia Urin sebelum diberikan senam kegel didapatkan frekuensi terbanyak pada Inkontinensia urin sedang yaitu sebanyak 16 orang lansia $(61 \%)$,

Tabel 5 Distribusi responden berdasarkan tingkat Inkontinensia urin setelah perlakuan

\begin{tabular}{|c|c|c|c|}
\hline No & Tingkat keparahan & frekuensi & Presentase \\
\hline 1 & Tidak Inkontinensia & 11 & $42 \%$ \\
\hline 2 & Inkontinensia Urin ringan & 4 & $15 \%$ \\
\hline 3 & Inkontinensia Urin sedang & 9 & $35 \%$ \\
\hline 4 & Inkontinensia Urin Berat & 2 & $8 \%$ \\
\hline 5 & $\begin{array}{c}\text { Inkontinensia Urin Sangat } \\
\text { berat }\end{array}$ & 0 & $0 \%$ \\
\hline \multicolumn{2}{|c|}{ Jumlah } & 26 & $100 \%$ \\
\hline
\end{tabular}

pada tabel. 5 setelah diberikan senam kegel menjadi tidak Inkontinensia urin sebanyak 11 lansia (42\%), inkontinensia urin ringan sebanyak 4 orang lansia (15\%), inkontinensia urin sedang 9 orang lansia (35\%), inkontinensia urin berat 2 orang lansia $(8 \%)$, dan frekuensi inkontinensia urin sangat berat $0 \%$.

1. Uji analisa Data

Dari Hasil analisis data inkontinensia urin pre dan post test menggunakan Uji wilcoxon dengan bantuan spss versi 21 didapatkan hasil nilai signifikansi $0.000 \leq 0.05$.

\section{PEMBAHASAN}

Inkontinensia urin adalah keluarnya urin yang tidak terkendali sehingga menimbulkan masalah higienis dan sosial. Inkontinensia urin dapat terjadi oleh beberapa faktor yakni usia (penuaan), penurunan hormone, gaya hidup (perokok) dan ISK. Beberapa faktor ini menyebabkan melemahnya otot dasar panggul. Otot dasar panggul adalah otot yang menyokong kandung kemih, sehingga ketika otot dasar panggul lemah kemudian ada rangsangan dari luar misalnya batuk, bersin, atau aktivitas yang cukup berat bisa menyebabkan pengeluaran urin tanpa terkontrol.

Inkontinensia urin paling sering terjadi pada lansia hal ini dikuatkan oleh penelitian yang dilakukan oleh Lubis (2009), hasil penelitiannya menjelaskan bahwa susunan tubuh termasuk otot mengalami penurunan hingga $80 \%$ pada usia 50-60 tahun. Hal ini senada dengan penelitian yang 
dilakukan oleh Sri Wulandari (2012) Pengaruh Latihan Bladder Training terhadap penurunan inkontinensia pada lanjut usia ditemukan bahwa inkontinensia urine terjadi pada responden yang memiliki usia $\geq 60$ tahun.

Pada saat peneliti melakukan studi pendahuluan dibalai sosial lanjut usia mandalika mataram, peneliti menggunakan kuisioner sandvix severity indeks (SSI) yang didalamnya terdapat 2 pertanyaan kemudian hasil skor dikalikan satu sama lain, peneliti menemukan ada 26 Lansia yang menderita Inkontinensia urin dari total 87 jumlah populasi dan secara keseluruhan lansia tersebut berusia $\geq 60$ tahun hal ini Senada dengan Jurnal tentang Prevalence of Urinary Incontinence oleh Thomas Thelma, dkk (1980), bahwa prevalensi penderita inkontinensia urine meningkat pada usia $\geq 60$ Tahun.

Beberapa penanganan baik dari farmakologis maupun nonfarmakologis dapat dilakukan untuk penyembuhan inkontinensia urin. Salah satu penanganan non farmakologis yang dapat membantu mengatasi Inkontinensia urin adalah senam kegel bertujuan untuk membangun kembali kekuatan otot dasar panggul. Senam ini dilakukan secara seri dengan tipe latihan kontraksi untuk meningkatkan kekuatan otot dasar panggul. Menurut Maas, et al (2011).

Latihan/Senam Kegel ini meningkatkan tonus otot dasar panggul, dengan menguatkan otot dasar panggul pada saat berkemih dirasakan, individu mampu menunda episode inkontinensia urine yang berhubungan dengan kelemahan otot panggul dan/atau kelemahan pintu keluar kandung kemih. Pada pengumpulan data awal (pretest) didapatkan hasil lansia terbanyak mengalami inkontinensia sedang sebanyak 16 orang lansia hal ini dikaitkan dengan masalah inkontinensia urin yang sudah di derita cukup lama oleh responden dan belum pernah diberikan penanganan baik farmakologis maupun non farmakologis ditambah lagi dengan proses penuaan yang terjadi di setiap hari nya mengakibatkan proses perjalanan masalah semakin bertambah parah. Setelah dilakukan senam kegel selama 6 minggu data tertinggi menunjukkan bahwa ada Lansia yang mengalami perubahan akibat pemberian senam kegel. Setelah dilakukan post test menggunakan kuisioner didapatkan data lansia tidak inkontinensia urin sebanyak 11 orang, 7 diantara nya mengalami penurunan tingkat inkontinensia urin dan 8 diantaranya tidak mengalami perubahan. Diperkirakan bahwa perubahan ini tidak terjadi terkait dengan adanya masalah masalah yang kompleks sehingga harus dilakukan pemeriksaan lebih lanjut. Ini sesuai dengan pernyataan Menurut penelitian yang dilakukan oleh Rahajeng (2010), bahwa tanpa latihan otot dasar panggul atau senam Kegel tidak akan ada perbaikan pada kekuatan otot dasar panggul. Sedangkan penelitian lain yang dilakukan di UPT Pelayanan Sosial Lansia dan Balita di wilayah Binjai dan Medan tahun 2012 dengan judul kegel exercise dengan penurunan gejala inkontinensia urin pada lansia diperoleh hasil latihan kegel efektif terhadap penurunan gejala inkontinensia urin pada lansia $(\mathrm{p}=0,004)$. (Septiasri dan Siregar, 2012 ) sedangkan Berdasarkan jurnal penelitian dari Park and Kang, 2014 dengan judul Pengaruh Latihan Kegel terhadap Penanganan Gangguan Inkontinensia urin pada wanita didapatkan hasil signifikan yaitu latihan kegel membantu menangani gangguan inkontinensia urin terutama wanita paruh baya.

Pada penelitian, ini peneliti mengajarkan lansia senam kegel sebanyak 2 kali sehari dalam 3 kali pertemuan selama seminggu dan akan diobservasi perubahan sampai 6 minggu perlakuan. Peneliti juga melakukan observasi setiap minggu dan ditemukan hasil perubahan mulai terjadi di minggu ke 4, 5 atau 6. Hal ini sesuai dengan pendapat Stanley \& Beare, 2006, Peningkatan dapat dilihat dalam waktu 4-6 minggu peningkatan maksimal. Sedangkan menurut Smeltzer, S.C., 2009, Latihan otot dasar panggul meliputi mengencangkan otot-otot yang digunakan untuk menghentikan flatus atau aliran urin selama 5 sampai 10 detik, kemudian ditingkatkan, selanjutnya istirahat selama 10 detik. Untuk efektifitas latihan ini perlu untuk dilaksanakan 2 atau 3 kali sehari sampai paling tidak selama 6 minggu.

Setelah 6 minggu perlakuan data pretest dan posttest diolah menggunakan uji wilcoxon dengan nilai signifikansi $\leq 0.05$. sebelum data diolah menggunakan uji wilcoxon terlebih dahulu peneliti melakukan uji normalitas data, dimana data prestest dan posttest diolah dengan uji Shapiro wilk untuk menentukan apa data berdistribusi normal atau tidak. Dan didapatkan hasil nilai signifikansi 0.001 yang artinya data tidak berdistribusi normal karena nilai $\leq 0.005$. 
sedangkan jika nilai signifikansi $\geq 0.05$ maka data berdistribusi normal. Dari hasil uji normalitas ini lah peneliti menggunakan uji wilcoxon. Setelah data dianalisa menggunakan uji wilcoxon didapatkan hasil nilai signifikansi $0.00 \leq 0.05$ yang artinya Ha diterima dan Ho ditolak ada pengaruh pemberian senam kegel terhadap inkontinensia urin pada lansia dibalai sosial lanjut usia mandalika mataram. Hal ini sesuai dengan pernyataan Maas et al, (2011) dalam jurnal Julianti Dewi Karjoyo, Damayanti Pangemanan, Franly Onibala (2017) tentang pengaruh senam kegel terhadap frekuensi inkontinensia urine pada lanjut usia di wilayah kerja puskesmas tumpaan minahasa selatan bahwa senam Kegel merupakan salah satu terapi non farmakologis bagi penderita inkontinensia urine yang tidak memiliki efek samping bila dilakukan secara rutin oleh para Lanjut usia untuk menguatkan otot dasar panggul sehingga dapat mengurangi frekuensi terjadinya inkontinensia urine. Hal ini juga sesuai dengan konsep latihan kegel dan pendapat seorang dokter kandungan bernama Kegel pada tahun 1940, bahwa latihan kegel sangat bermanfaat untuk menguatkan otot rangka pada dasar panggul, sehingga memperkuat fungsi sfingter eksternal pada kandung kemih (Septiastri \& Siregar, 2012)

\section{SIMPULAN}

Berdasarkan penelitian yang dilakukan di Balai Sosial Lanjut Usia Mandalika Mataram didapatkan hasil : terdapat 26 lansia yang mengalami inkontinensia urin . Data pre dan post test menunjukkan inkontinensia paling banyak dialami yaitu Inkontinensia sedang sebanyak 16 orang lansia (61\%), setelah diberikan senam kegel menjadi 8 orang lansia (31\%) yang mengalami Inkontinensia Sedang, Data kemudian di analisis menggunakan Uji wilcoxon didapatkan nilai signifkansi 0.00 yang artinya $\leq 0.05$ maka dapat disimpulkan bahwa ada pengaruh pemberian senam kegel pada lansia yang mengalami inkontinensia urin

\section{DAFTAR PUSTAKA}

Anggelita ,2012. Latihan Kegel dengan Penurunan Gejala Inkontinensia Urine pada Lansia.

Arikunto, Suharsimi. (2012). Prosedur Penelitian Suatu Pendekatan Praktek. Jakarta: Rineka Cipta

Aspiani. R.Y. 2014. Asuhan Keperawatan Gerontik. Jakarta : CV Trans Info Media

Badan Pusat Statistik. 2014. Statistik Penduduk Lanjut Usia: tersedia di http://old.bappenas.go.id/files/data/Sumber_Daya_Manusia_dan_Kebudayan/Statistik \%20Penduduk\%20Lanjut\%20Usia\%20Indonesia\%202014.

Balai Sosial Lanjut Usia Mandalika Mataram. 2018. Daftar Penyakit Kelayan Balai Sosial Lanjut Usia Mandalika Mataram. Mataram : Balai Sosial Lanjut Usia Mandalika Mataram

Daley, D. (2014). 30 Menit untuk Bugar \& Sehat . Jakarta: PT Bhuana Ilmu

Departemen Kesehatan RI. 2017. Profil Kesehatan Indonesia. Jakarta: Departemen Kesehatan RI.tersedia di http://www.pusdatin.kemkes.go.id/resources/download/pusdatin/profilkesehatan-indonesia/Data-dan-Informasi_Profil-Kesehatan-Indonesia-2017.pdf

Dinas Kesehatan Provinsi NTB. 2018. Statistik Lanjut Usia Provinsi NTB. Mataram : Dinas Kesehatan Provinsi NTB

Karjoyo, J.D. 2017. Pengaruh Senam Kegel terhadap frekuensi inkontinensia urine pada lanjut usia di wilayah kerja puskesmas tumpaan Minahasa selatan. tersedia di : https://media.neliti.com/media/publications/107046-ID-none.pdf

Kementerian Kesehatan RI. 2013. Pusat Data dan Informasi. Jakarta Selatan: Kementerian Kesehatan RI. tersedia di http://www.depkes.go.id/resources/download/pusdatin/profil-kesehatanindonesia/profil-kesehatan-indonesia-2013.pdf

Kementerian Kesehatan RI. 2017. Pusat Data dan Informasi. Jakarta Selatan: Kementerian Kesehatan RI tersedia di http://www.pusdatin.kemkes.go.id/resources/download/pusdatin/profil-kesehatanindonesia/Data-dan-Informasi_Profil-Kesehatan-Indonesia-2017.pdf

Maryam, R. Siti, dkk. 2012. Mengenal Usia Lanjut dan Perawatannya. Jakarta: Salemba Medika. 
Notoatmodjo, Soekidjo. 2014. Metode Penelitian Kesehatan. Jakarta : Rineka Cipta.

Novera, M. 2016. Pengaruh senam kegel terhadap frekuensi BAK pada lansia dengan inkontinensia urin di Panti Sosial Tresna Werdha Sabai Nan Aluih. Tersedia di : http://ejournal.kopertis10.or.id/index.php/jit/article/viewFile/589-7878/pdf21

Nugroho, W. 2008. Keperawatan Gerontik dan Geriatrik Edisi 3. Jakarta : Buku Kedokteran EGC

Nurwidiyanti, E. 2014. Pengaruh kegel exercise terhadap inkontinensia urin pada lansia. Tersedia di : http://jurnal.akpernotokusumo.ac.id/index.php/jkn/article/download/24/24

Sandvix. 1993. Sandvix Severity Index. Tersedia di : https://www.google.co.id/search?q=KUISIONER+SANDVIX+SEVERITY+INDEKS \&oq=KUISIONER+SANDVIX+SEVERITY+INDEKS\&aqs=chrome..69i57.12616j0j 7\&sourceid=chrome\&ie $=$ UTF-8

Sulistyaningsih, D. 2015. Latihan otot dasar panggul efektif untuk mengatasi inkontinensia urin pada klien post operasi prostatectomy. http://jurnal.unissula.ac.id/index.php/jnm/article/download/465/386

Wahyudi, A.S. 2017. Pengaruh latihan senam kegel terhadap frekuensi berkemih pada lansia. https://docplayer.info/181158-Pengaruh-latihan-bladder-training-terhadap-penurunaninkontinensia-pada-lanjut-usia-di-panti-wreda-dharma-bakti-surakarta-skripsi.html

Wulandari,S. 2012. Pengaruh Latihan Bladder Training terhadap penurunan inkontinensia pada lanjut usia.https://docplayer.info/181158-Pengaruh latihan-bladder-training-terhadappenurunan-inkontinensia-pada-lanjut-usia-di-panti-wreda-dharma-bakti-surakartaskripsi.ht 